\title{
Response of the International Monetary Fund and the European Union to the Global Financial Crisis
}

\author{
Jeta Nushi \\ PhD Candidate, European University of Tirana \\ jeta_n@hotmail.com
}

Doi:10.5901/ajis.2014.v3n2p191

\section{Abstract}

The aim of the paper is to show the evolution of the global crisis, its involvement and to discuss the response of the International Monetary Fund and the European Union to the global financial crisis. In this paper I will try to cover the following issues: The first part of the paper deals with the history of the evolution of the global financial crisis and its enlargement in the euro zone, by identifying the causes of the crisis in the European market from 2006. In the second part will be discussed for drafting emergency plans that were used to set up all the possible "barricades" of the enlargement and the exposure of entire global financial system. Further will be explained the reaction of IMF and EU to global crisis and which were the rescue packages from the IMF and EU. Will be explained the role of European stability mechanisms, allocation of funds to the countries most affected by the financial crisis and financial assistance programs for EU declarations since 2008. In the end will be explained what measures were taken to prevent this crisis and according to analysts the period after the crisis there will be an economic growth from 2011-2025

Keywords: financial global crisis, International Monetary Fund, European Union, European stability, debt crisis, financial mechanisms.

\section{Introduction}

Eurozonewas just celebrating it decade of existence when the global financial crisis of 2007 has been transformed into an European crisis of the public debt. Initially started in USA and then has been transferred in Europe and Asia. The debt crisis sank Greece, Ireland, Portugal, Spain and many other countries of Europe. Euro zone countries, affected by the crisis, were forced to sequentially require emergency financial assistance because the crisis threats the European countries existence. To prevent this crisis the International Monetary Fund and the UE countries, less affected by the crisis, intervened by giving financial assist to pass the debt crisis and economic problems.

\section{The evolution of the global financial crisis and its spread in the Eurozone}

Was just finished the spring of 2007! Quite suddenly the terrible word "financial crisis" began to spread rapidly. Born in the U.S., it seemed that soon will cover with panic the whole world (Civici, A. 2010, p 13). The word "subprime" which until that period had expressed only one of the forms of mortgage loans with high risk in the U.S., immediately became a symbol of the horrors of the crisis (Beqa, B. 2009).Meanwhile, America began to publish accounts before staggering financial loss, banks and financial markets throughout the world began to shake. Meanwhile, America began to publish accounts before staggering financial loss, banks and financial markets throughout the world began to shake. Up to this time it seemed that everything in the world went marvellously, U.S., Europe, China, etc., had a satisfactory growth and constant, the growth of the entire planet was the fastest in the history, the poverty began to diminish in Asia and Latin America, science and technology were in a very dynamic progress by creating more and more world-oriented opportunity for sustainable development for hundreds of millions of people. There was no apparent warning or signs that could attract serious attention, in July 2008 economies of the planet's most powerful financial systems start the path to a depression, the worst of the last eighty years. Debates began on the causes of the crisis and the culprits who caused it. It seems that in early 2008, the global financial crisis that began and exploded in the U.S. began to spread to Europe. And that is reflected in a large number of national economies in Europe. Many researchers have predicted a series of negative shocks of aggregate demand for the European economy, and identifying the immediate causes of the crisis in the European market and they were:

- High prices of raw materials: Where oil prices rose more than double in the period from the beginning of 2007 - 
2008 (from $40 €$ / barrel to $90 €$ / barrel)

- On the strong price of euro:The euro appreciated against the dollar that was still the main currency of the world, from \$ 1.20 to \$1.60, which was more than 33\% from early 2006 to 2008 . Where the nominal interest rate of the euro was up to $15 \%$ in 2008.

- The effect of higher interest rates through the transmission mechanism: The ECB had begun to increase interest rates since 2006. Rates were increased eight times in the range of $2.0-4.0 \%$ by mid of 2007,taking into account that inflation was caused mainly by the increase of import prices (Killibarda, M., Nikćević A., Milić D.\&Mićunović A. 2011, p 13,14).

Plans were developed to undertake urgent action and to control the crisis. In this point of view begun to develop the necessary financial and economic policies of many governments and central banks to set up "roadblocks" in way to prevent the spread and infection of all world financial system (Civici, A. 2010, p 16).

\section{The IMF and the EU response to the crisis}

With the advent of the financial crisis in the euro zone also came new relationships in the EU report - IMF1. Eurozone countries should take a big step towards integration with the support of a new cross-border coordination budget system. Eurozone had to set short-term fiscal transfers between euro-zone members to avoid a repeat of the crisis. According to a new prescription of the IMF, the budget system proposed had been a step towards a common centralized economic management within the Euro zone. But, it is necessary a better internal fiscal flows control, respectively enhancing the coordination in fiscal and economic policy plan (Petrović P.\&Živković A. 2010). Due to the strong financial integration of the euro zone, respectively the ability to easily transfer the crisis from one country to another, it was necessary to build a system for ensuring the financial stability of the euro zone and to respond with appropriate policies. This policy has included crisis management and systematic measures to ensure fiscal sustainability, long-term growth, cash balance, revitalize and reinforce the financial system, as well as providing assistance to the most vulnerable members.

\section{Mechanisms of crises and packages to help vulnerable countries}

EU and IMF have responded to the crisis by providing rescue aid package for the affected country called"Rescue umbrella" in the amount of 750 billion euros. On the basis of the aid package, the European Union created two mechanisms:

1. European financial stability mechanism (EFSM) and

2. European Fund of financial stability (EFSF).

- European financial stability mechanism was initially conceived for Eurozone Member States. The financial mechanism means could be used by all the EU members. Funds for this mechanism (60 billion euros) are allowed by the European Commission by its own funds. The creation of the European Fund for financial stability provided landings to the member countries within the euro zone in a total of 440 billion with preferential interest rates.The total asset of the funds for the two mechanisms was 500 billion Euros. Mechanisms have been established for a period of three years in order to facilitate access to free financial resource for vulnerable countries. IMF provided a special fund in the amount of 750 billion Euros allocated to Greece (110 billion Euros), Ireland (85 billion Euros) and Portugal (78 billion Euros). Creditors in Greece, Portugal and Spain are mainly foreign creditors; therefore fulfilling the obligations in time is considered the most challenging for those countries considering the loss of confidence in financial markets. The last meeting of the EU countries in July 2011 resulted in a package that would cover Greece's financing needs by decreasing interest rates and extending the period for recovery of loans that Greece has received from countries EU and IMF. Simultaneously with the formation of mechanisms has reacted ECB, which began buying government bonds, vulnerable members of the IMF, which provided a loan of 250 billion Euros(Killibarda, M., Nikćević A., Milić D.\&Mićunović A. 2011, p 19,20,21). As shown in Table 1.

${ }^{1}$ International Monetary Found (IMF) is a self-described "organization of 188 countries, working to foster global monetary cooperation, secure financial stability, facilitate international trade, promote high employment and sustainable economic growth, and reduce poverty around the world. http://en.wikipedia.org/wiki/International_Monetary_Fund 
Table 1.The main characteristics of EFSM, EFSF and ESM

\begin{tabular}{|c|c|c|}
\hline \hline EFSM & EFSF & ESM \\
\hline \hline \multicolumn{3}{|c|}{ The amount of funds } \\
\hline 60 billion euro & In0 billion euro & 500 billion euro \\
\hline \multicolumn{2}{|c|}{ Instruments (equipment) } \\
\hline Loans & Loans + buying bonds in the primary market & Loans + buying bonds in the primary market \\
\hline & Rating & \\
\hline \multicolumn{2}{|c|}{ AAA rating } & Eurozone members \\
\hline EU members & Members & Perm from July 1, 2013 \\
\hline \multicolumn{2}{|c|}{ Eurozone members } \\
\hline 30 June 2013
\end{tabular}

Source: EFSF (http://www.efsf.europa.eu/about/index.htm?lang=-en)

Duration of the European Financial Stability Fund was originally set up in June 2013. But, loans are given to the countries for a longer period than the intended duration. Therefore, the Fund's duration was extended indefinitely under the new name of the European Stability Mechanism² $(E S M=M S E)$. This mechanism would effectively dispose of assets in the amount of 500 billion euros and is expected to replace the two previous mechanisms after following their termination in 2013. MSE will buy bonds of member states that are in financial difficulties, with the condition that the country adopts a program of revitalization (revival) of its finances and to fully implement it (. Unlike previous mechanisms, MSE will involve the private sector, in accordance with the rules of the IMF. MSE will operate as an intergovernmental institution in accordance with public law. The Crisis Mechanism is designed to strengthen the accountability of states, so that financial aid is not intended to prevent the formation of new problems, but to solve the existing ones.

Table 2. Assistance programs for countries affected EFSF and EFSM

\begin{tabular}{|c|c|}
\hline \hline 2011 & 2012 \\
\hline $\begin{array}{c}\text { EFSF } \\
16.5 \text { billion euro }\end{array}$ & 10 billion euro \\
\hline BFSM September 2011 attracted 3.3 billion & \\
\hline EFSM 17.6 billion euro & 4.9 billion euro \\
\hline By September 2011 attracted 13.9 billion euro & \\
\hline
\end{tabular}

Source: EFSF (http://www.efsf.europa.eu/attachments/201104-efsf-newsletter-n01.pdf)

In early 2010, European officials have put the idea of creating a European Monetary Fund to increase economic cooperation and supervision in the euro zone. The European Commission has expressed its willingness to propose such instrument with the support of all members of the euro zone. European Monetary Fund would react if a member of the euro zone needs financial support. Had mastered the strict control mechanisms and sentenced Member States that do not comply with the rules in way to: prohibit the use of subsidies from European funds, to suspend his right to vote at the ministerial level, to prohibit the right to use the euro and the temporary exclusion from the euro zone. The European Union has reacted with 236 billion euro "as injection" equity in financial institutions in the period October 2008 - May 2010(Killibarda, M., Nikćević A., Milić D.\&Mićunović A. 2011, p 21).

2 The European Stability Mechanism (ESM) is an international organisation located in Luxembourg which was established on 27 September 2012 as a permanent firewall for the eurozone to safeguard and provide instant access to financial assistance programs for member states of the eurozone in financial difficulty. It replaced two earlier temporary EU funding programmes: the European Financial Stability Facility (EFSF) and the European Financial Stabilisation Mechanism (EFSM). http://en.wikipedia.org/wiki/European_Stability _Mechanism 
Table 3. Assistance programs for members of the EU (since 2008)

\begin{tabular}{|c|c|c|c|c|c|c|c|c|c|c|c|}
\hline Eu member & $\begin{array}{c}\text { Time } \\
\text { span }\end{array}$ & $\begin{array}{c}\text { IMF } \\
\text { (billion€) }\end{array}$ & $\begin{array}{c}\text { World } \\
\text { Bank } \\
\text { (billion€) }\end{array}$ & $\begin{array}{c}\text { EIB/EBRD } \\
\text { (billion€) }\end{array}$ & $\begin{array}{c}\text { Bilateral } \\
\text { (billion€) }\end{array}$ & $\begin{array}{c}\text { Bop } \\
\text { (billion€) }\end{array}$ & $\begin{array}{c}\text { GLF } \\
\text { (billion€) }\end{array}$ & $\begin{array}{c}\text { EFSM } \\
\text { (billion€) }\end{array}$ & $\begin{array}{c}\text { EFSF } \\
\text { (billion€) }\end{array}$ & $\begin{array}{c}\text { ESM } \\
\text { (billion€) }\end{array}$ & $\begin{array}{c}\text { Bailout in } \\
\text { total } \\
\text { (billion€ }\end{array}$ \\
\hline Cyprus I & $\begin{array}{c}\text { Dec.2011- } \\
\text { Dec.2012 }\end{array}$ & - & - & - & 2.5 & - & - & - & - & - & 2.5 \\
\hline Cyprus II & $\begin{array}{c}\text { May 2013- } \\
\text { Mar.2016 }\end{array}$ & 1.0 & - & - & - & - & - & - & - & 9.0 & 10.0 \\
\hline Greece & $\begin{array}{c}\text { May 2010- } \\
\text { Mar.2016 }\end{array}$ & $48.1(20.1+19.8+8.2)$ & - & - & - & - & 52.9 & - & 144.6 & - & 245.6 \\
\hline Ireland & $\begin{array}{c}\text { Nov.2010- } \\
\text { Dec.2013 }\end{array}$ & 22.5 & - & - & 4.8 & - & - & 22.5 & 17.7 & - & 67.5 \\
\hline Portugal & $\begin{array}{c}\text { May 2011- } \\
\text { May 2014 }\end{array}$ & 26 & - & - & - & - & - & 26 & 26 & - & 78 \\
\hline $\begin{array}{c}\text { Total } \\
\text { payment }\end{array}$ & $\begin{array}{c}\text { July 2012- } \\
\text { Dec.2013 }\end{array}$ & - & - & - & - & - & - & - & - & 41.4 out of \\
Mar.2016-
\end{tabular}

Source: Wikipedia (http://en.wikipedia.org/wiki/European_Stability_Mechanism)

Table gives an overview of the composition of the entire financial bailout programs initiated for EU countries, since the global financial crisis that erupted in September 2008. Since October 2012, the ESM as a permanent fund of financial stability, to cover any possible future aid packages within the Eurozone, has effectively replaced the late GLF + funds + EFSF EFSM. Whenever promised funds for a planned program of assistance were not full transferred.

\section{Conclusion}

Every day more and more, referring to unemployment figures many countries, including the U.S., EU, Russia, etc., with the stagnation of many economies on the planet, it seems that the crisis continues to be present adding the concerns for crisis extension and its effects. Not only the U.S., EU countries, Japan, etc., but also countries classified as "rapidly developing economies" such as China, India, Brazil, Russia and Mexico are constantly revising the forecasts for economic financial performance for the coming years, especially those of medium term 2010-2015. This group was joining also by developing and poor countries who feel even more threatened by the effects of the crisis. Proposals and alternatives to come out of crisis with less economic and social costs have been numerous as: "Paulson plan", "Obama package", "Merkel proposal", "Sarkozy plan", "The package of measures and policies of the IMF", "The World Bank plan to face the crisis", etc. Also stand in front of them concerns and various alternatives in relation to the proposed packages of the main leaders of the most developed countries of the world and those of greater economic institutions. After this crisis has no doubt that the world and its economy will begin a new cycle, a new era in terms of its organization and operation. Ultimately, many analysts and crises experts, consider that if we put in balance the concerns and suggestions for to face the crisis andbreak out of it, with the concerns and suggestions for fundamental structural reform of the postcrisis period, the largest proportion of these skewed in both of them. Ultimately, the perspective of economists is that the crisis is part of ups and downs scenario cycle that occurs routinely in the capitalist system. The World Bank has predicted that in 2025 six major emerging economies (Brazil, India, China, Indonesia, South Korea and Russia) will claim more than half of global growth, as well as in the international monetary system will not dominate a single currency. The emerging economies in the period 2011-2025 will grow on average by $4.7 \%$ and their share in global GDP will rise from 36\% to $45 \%$.

\section{References}

Beqa, B. (2009), Krizafinanciareapoglobale: efektetshkatëruesetësaj, Albania

Civici, A. (2009), Globalizimi ... ANTE PORTAS, UET Press, Tirana

Civici, A. (2010), Krizafinanciareapoglobale, UET Press, Tirana

EEAG (2011), The EEAG Report on the European Economy: A new Crisis Mechanism for the Euro Area, Chapter 2

European Financial Stability Facility (EFSF) Report. (2013). Retrieved from: (http://www.efsf.europa.eu/attachments/faq_en.pdf (accessed February 26, 2014) 
Economic and Financial Affairs: Balance of Payments [web site], Retrieved from: http://ec.europa.eu/economy_finance/eu_borrower /balance_of_payments/index_en.htm (accessed March 5, 2014)

Economic and Financial Affairs: Financial assistance to Greece [web site], Retrieved from: http://ec.europa.eu/economy_finance lassistance_eu_ms/greek_loan_facility/index_en.htm(accessed March 6, 2014)

European Financial Stability Facility [wēb site], Retrieved from: http://www.efsf.europa.eu/about/index.htm(accessed March 10, 2014)

European Financial Stability Facility: Ireland's exit [web site], Retrieved from: http://www.efsf.europa.eu/about/operations /ireland/index.htm(accessed March 10, 2014)

European Stability Mechanism [web site], Retrieved from: http://en.wikipedia.org/wiki/European_Stability_Mechanism(accessed March 10, 2014)

International Monetary Fund [web site], Retrieved from: http://en.wikipedia.org/wiki/International_Monetary_Fund(accessed March 2, 2014)

Klibarda,M.,Nikčevič,A.,Milič,D. and MičunovičA. (2011), Globalnafinansijskakriza I odgovorevropskeunije.Centralna Banka Crne Gore, Podgorica

Petrović, P.,andŽivković, A. (2010), FinansijskakrizaiformiranjeEvropskogMonetarnog Fonda. Vol. LXII. br4. sur. 585-601 
